\title{
EMPREENDIMENTOS TURÍSTICO-IMOBILIÁRIOS E A MODERNIZAÇÃO DOS LITORAIS METROPOLIZADOS FORTALEZA - CEARÁ.
}

\author{
Alexandre Queiroz Pereira ${ }^{1}$ \\ Gabriela Bento Cunha ${ }^{2}$
}

\section{Resumo}

As metrópoles nordestinas passavam por intensas transformações de ordem política, econômica e social no início da década de 1970. O processo de metropolização desenvolveu-se sobre a região e, como consequência, intensificou as relações de (re) produção do espaço urbano. Assim, o objetivo deste artigo é entender o processo de metropolização de Fortaleza, a dinâmica socioespacial contemporânea e seus desdobramentos, com foco na urbanização litorânea, nas atividades de lazer, e, mais especificamente, nas formas e funções urbanas derivadas. Com dados coletados em trabalhos de campo (observações in loco, entrevistas com informanteschave e descrição elementar via caderneta de campo), analisamos as práticas marítimas como um vetor de expansão urbana da metrópole.

Palavras-chave: Urbano, Turismo, Práticas marítimas.

\section{TOURISM-REAL ESTATE ENTERPRISES AND THE MODERNIZATION OF THE METROPOLIZED COASTAL - FORTALEZA - CEARÁ.}

\begin{abstract}
The Northeastern metropolis underwent intense political, economic and social transformations in the early 1970s. The process of metropolization develops over the region and, as a consequence, intensifies the (re) production relations of the urban space. So, the objective is to understand the Fortaleza metropolization process, contemporary socio-spatial dynamics and its developments, with a focus on coastal urbanization, leisure activities, and more specifically on derived urban forms and functions. With information collected in field job (on-site observations, interviews with key informants and elementary description via field book), we analyze like maritime practices as a vector of urban expansion of the metropolis.
\end{abstract}

Key-words: Urban, Tourism, Maritime Practices.

\footnotetext{
1 Professor Adjunto no Departamento de Geografia da UFC. É, também, pesquisador do Observatório das Metrópoles - Núcleo Fortaleza, coordenando o Laboratório de Planejamento Urbano e Regional da Universidade Federal do Ceará. E-mail: aqpufc@gmail.com.

${ }^{2}$ Mestre em Geografia pela Universidade Federal do Ceará. Desenvolve pesquisas na área de metropolização turística e dos lazeres. Vinculada ao Laboratório de Planejamento Urbano e Regional - LAPUR - UFC e Observatório das Metrópoles. E-mail: gabibento.c@gmail.com
} 


\section{EMPLEO TURÍSTICO-INMOBILIARIOS Y LA MODERNIZACIÓN DE LOS LITORALES METROPOLIZADOS - FORTALEZA - CEARÁ.}

\section{Resumen}

Las metrópolis nordestinas pasaban por intensas transformaciones de orden político, económico y social a principios de la década de 1970. El proceso de metropolización se desarrolla sobre la región y, como consecuencia, intensifica las relaciones de (re) producción del espacio urbano. Así, el objetivo es entender el proceso de metropolización de Fortaleza, la dinámica socioespacial contemporánea y sus desdoblamientos, con foco en la urbanización costera, en las actividades de ocio, y más específicamente, en las formas y funciones urbanas derivadas. Con datos recogidos en trabajos de campo (observaciones in loco, entrevistas con informantes clave y descripción elemental vía cuaderno de campo), analizamos las prácticas marítimas como un vector de expansión urbana de la metrópoli.

Palabras-clave: Urbano, Turismo, Prácticas Maritimas.

\section{INTRODUÇÃO}

No início da década de 1970 as cidades nordestinas passaram por intensas transformações de ordem política, econômica e social. É diante desse contexto que o processo de metropolização desenvolveu-se sobre a região e intensificou as relações de (re) produção do espaço urbano. Para Lencioni (2013) a metropolização do espaço se constitui no processo socioespacial que transforma profundamente o território. Assim, entender a metropolização de Fortaleza é entender a dinâmica socioespacial contemporânea e seus desdobramentos que, nessa abordagem, terá foco na urbanização litorânea, nas atividades de lazer, e, mais especificamente, nas formas urbanas e funções derivadas.

$\mathrm{Na}$ formação da Região Metropolitana de Fortaleza (RMF), vetores de expansão foram identificados: trata-se de espacialidades regidas pelos processos de industrialização (nos trechos localizados nos municípios de Maracanaú, Pacajus, Horizonte e São Gonçalo do Amarante, principalmente) e da disseminação das práticas de lazer marítimo (sobretudo em Aquiraz, Caucaia e São Gonçalo do Amarante).

As transformações pelas quais as metrópoles nordestinas têm passado relacionam-se, principalmente, à incorporação do mar, das práticas marítimas modernas e da atividade turística (DANTAS, 2009). Mudanças que ocasionaram redefinições na (re) produção do espaço urbano em trechos do território à beira-mar. A partir da década de 1990, houve o crescimento econômico e a diversificação da atividade turística na região Nordeste. Tais atividades 
ganharam importância como vetor da produção do urbano, sobretudo, em trechos litorâneos da região.

Este texto busca compreender os desdobramentos do lazer litorâneo na disseminação do tecido urbano frente à instalação e operação de empreendimentos turísticos associados e, também, ao mercado imobiliário de segundas residências no litoral metropolitano de Fortaleza.

Como metodologia de análise ${ }^{3}$, utilizou-se de dados coletados em trabalhos de campo (observações in loco, entrevistas com informantes-chave e descrição elementar via caderneta de campo), sistematizados em uma cartografia temática inicial e avaliados sob a perspectiva da produção do espaço urbano ${ }^{4}$. Foram utilizados imagens de satélite de três recortes temporais (2000, 2008 e 2016) como instrumento de detecção da ocupação do território. Consideraramse, simultaneamente, teorias e estudos de casos desenvolvidos por pesquisadores especialistas em metropolização e valorização dos espaços litorâneos no mundo e, sobretudo, no Nordeste brasileiro.

O artigo aponta, inicialmente, uma discussão acerca da metropolização do espaço em função do lazer marítimo na escala nordestina, com ênfase na escala cearense. Adiante, abordase a instalação dos empreendimentos turístico-imobiliários e suas formas urbanas, tanto na Praia do Porto das Dunas como no Cumbuco, litorais situados na Região Metropolitana de Fortaleza. Ainda nesse tópico, há correlação desses empreendimentos com a expansão do tecido urbano. Nas considerações finais argumentam-se como esses equipamentos corroboram para o processo de urbanização litorânea dessas localidades.

\section{METROPOLIZAÇÃO EM ESPAÇOS DO LAZER MARÍTIMO}

Ainda que o desejo e atração pelo mar em outros países seja um dos indicadores para a mudança de mentalidade da sociedade brasileira, não ocorre aqui uma relação com a maritimidade igual às demais. Dantas explica (2006, p. 17) "adota-se uma abordagem cultural, no sentido de compreender a relação dos homens com o mar nos trópicos”. Essa abordagem

\footnotetext{
3 Esse estudo foi desenvolvido no projeto de pesquisa: "Vilegiatura marítima e a constituição da região metropolitana de Fortaleza", financiado pelo CNPq/Universal com a colaboração da Fundação Cearense de Apoio ao Desenvolvimento Científico e Tecnológico - FUNCAP.

${ }^{4}$ Os dados apresentados neste artigo, bem como a produção cartográfica, são resultados da conclusão da pesquisa de Mestrado de um dos autores, intitulada: "Urbanização litorânea e planejamento na metrópole: a produção do espaço urbano de Fortaleza.”.
} 
sugere a ideia de ser o desejo pelo mar no Brasil de padrões próximos, e não idênticos, ao da invenção da praia no ocidente.

Os espaços litorâneos metropolitanos foram incorporados ao lazer dos citadinos e na instalação das residências de veraneio. À medida que esse processo ocorria, com ênfase na década de 1990, o crescimento da atividade turística e a sua consolidação no Nordeste brasileiro gerou a "descoberta" ou a "reinvenção" dos lugares à beira-mar. A intensificação das atividades turísticas em trechos dos municípios metropolitanos litorâneos permitiu que as empresas privadas e os incorporadores imobiliários criassem projetos para o consumo desses espaços. O resultado aconteceu através dos complexos de lazer e na diversificação dos empreendimentos turístico-imobiliários ${ }^{5}$. Com isso, esses espaços tornaram-se propícios para a disseminação da vilegiatura marítima ${ }^{6}$ e sua reprodução, sobretudo, ao atrair brasileiros de outras regiões e estrangeiros.

As funções e as formas urbanas inerentes ao lazer no litoral nordestino derivam do processo de incorporação e valoração das zonas de praia. Tal processo vincula-se às transformações de ordem econômica e social, mas, também, perpassa uma ação política de planejamento do Estado (com a criação de leis e projetos que intensificam a valorização desses espaços e a transformação da morfologia urbana - notadamente o PRODETUR) e da iniciativa privada (incorporação imobiliária, construção de empreendimentos de padrão internacional, modernização de atrativos turísticos e divulgação midiática das localidades).

Entende-se que as transformações culturais ocorridas no Brasil vinculam-se ao mundo contemporâneo e à troca de valores nos países ocidentais. Acrescenta-se a essa ótica a perspectiva do homem moderno, acompanhando o pensamento Lefebvriano, incluído na lógica capitalista de produção e reprodução do espaço. Nesse contexto, o papel da sociedade na transformação do espaço e da zona costeira ocorre também em virtude da necessidade de lazer e da incorporação econômica das zonas de praia.

A valorização das zonas costeiras no Nordeste brasileiro vincula-se aos interesses de uma sociedade resultante do desenvolvimento urbano e industrial. Esse processo, também,

\footnotetext{
${ }^{5} \mathrm{O}$ imobiliário turístico, oriundo do fenômeno de "segundas-residências", está pautado na segunda habitação para estadias de durações que variam desde um simples fim de semana até mesmo a permanências mais longas como, por exemplo, as temporadas de férias. Tratado como um tipo de alojamento turístico, porém, distante de ser um meio de hospedagem tradicional. (CIRILO, 2009).

${ }^{6}$ A vilegiatura acontece quando indivíduos ou grupos sociais reservam em seu cotidiano um recorte espaçotemporal onde as necessidades dos praticantes (lazer) serão atendidas, ou seja, o gozo está na condição de se sedentarizar temporariamente em outro lugar que não seja sua residência, sua moradia. (PEREIRA, 2014).
} 
ocorreu em outros países subdesenvolvidos que encontraram no litoral uma natureza de enorme valor mercadológico e estímulo para o crescimento econômico. Dessa forma, a atividade turística se configura em um conjunto de atores, territórios e paisagens que produzem novas formas espaciais e padrões de consumo.

Nesse contexto, uma série de mudanças ocorre alterando a ocupação da zona costeira e agregando a ela, além da moradia, um valor de status social. Com a dinamização do mercado de trabalho, criação de instituições públicas, fortalecimento de uma classe média, inserção da mulher na cadeia econômica, abertura de vias de acesso e a circulação de informações, a demanda por lazer passa a representar, também, um novo estilo de vida: uma fuga do cotidiano, contato com a natureza e, mais dialeticamente, a reprodução do espaço urbano.

A "descoberta" do Nordeste como espaço propício para a turistificação gerou, além do aumento do fluxo, uma grande oportunidade para o mercado imobiliário e a iniciativa privada. Rodrigues (1996, p. 149) conclui que "o Nordeste começou a ser vendido como o Novo Caribe, Novo Mediterrâneo, a Nova Flórida. As iniciativas isoladas dos governos estaduais resultam num significativo aumento dos fluxos". Dessa forma, ela acrescenta que "começam a se tornar importantes os capitais estrangeiros injetados no setor, na forma de construção de hotéis e resorts, nos moldes dos grandes centros turísticos internacionais".

A institucionalização das regiões metropolitanas ocorreu em meados de 1970 e se faz necessário dissociar o processo de metropolização e o de criação das regiões metropolitanas, bem como a análise de metrópole e o de região metropolitana. A metropolização reflete um espaço dinâmico, urbanizado, tecnificado, com relações socioespaciais diversificadas e inerentes ao processo de globalização e ao sistema capitalista. A região metropolitana é definida por limites, pela articulação de municípios e por uma política urbana (seja ela estadual ou regional).

É válido ressaltar que o processo de metropolização não se restringe à formalização das regiões metropolitanas, mas com a sua regulamentação os estados tiveram mais representatividade. Assim, com a autonomia estabelecida, novas práticas de desenvolvimento são pensadas. Nas proximidades das grandes aglomerações urbanas situadas no litoral, principalmente nos trópicos, houve crescente atenção às atividades de lazer, tanto públicas como privadas. Esse processo reflete uma dinâmica de desenvolvimento pensada para os países subdesenvolvidos, em especial, os da América Latina. 
O processo de urbanização das metrópoles, cidades e vilarejos litorâneos nordestinos engloba as transformações no modelo de sociedade: a valorização das zonas de praia como espaço de moradia (status para a elite) e de lazer (enquadram-se aqui tanto as práticas de turismo e vilegiatura e, também, a praia como espaço de encontro e de relações sociais). Isso não se restringe aos limites fronteiriços, mas sim à sociedade e a produção do espaço, do lazer e do urbano.

Nas aglomerações urbanas nordestinas compreende-se que há uma diversidade de espaços e produtos que não se limitam aos recortes institucionais dos municípios. São considerados subespaços internos às metrópoles que não formam uma morfologia contínua. Macedo e Pelegrino (1999) abordam que esses subespaços compõem a morfologia urbana litorânea que conhecemos hoje.

Com isso, a metrópole cearense estende-se e promove a metropolização do espaço, similar ao que ocorre nas demais metrópoles nordestinas (Recife, Natal e Salvador). Limonad (2006, p. 33) explica que "a urbanização é entendida, aqui, como um processo que não está mais restrito à cidade, que extravasa os limites da aglomeração física de edificações, infraestruturas e atividades, de fixos e fluxos, através das diversas práticas, táticas e estratégias dos distintos capitais e do trabalho para garantir sua reprodução". Entende-se que o processo é composto pelo transbordamento das relações de produção e de lazer e a formação de novos espaços regidos pela dinâmica do capital e da produção do espaço urbano. Dessa forma, a paisagem litorânea nordestina é, hoje, formada por uma urbanização dispersa, paralela à costa (linearidade) e não contínua (formada por manchas e fragmentos do urbano), regida por atividade baseada na sazonalidade dos fluxos.

A expansão da mancha urbana litorânea explicita como o processo de urbanização se encontra intenso nos municípios próximos da cidade polo da metrópole, gerando subespaços regidos pelo lazer e pelo urbano. Isso pode ser analisado diretamente no contexto cearense. Se antes o crescimento dos grandes centros urbanos nordestinos ocorria, em muitos casos e somente, em decorrência da instalação de indústrias, atualmente um dos vetores dessa expansão se dá pelo fortalecimento da atividade turística e de lazer (figura 1). 
Figura 1: Vetores de expansão urbana da Região Metropolitana de Fortaleza.

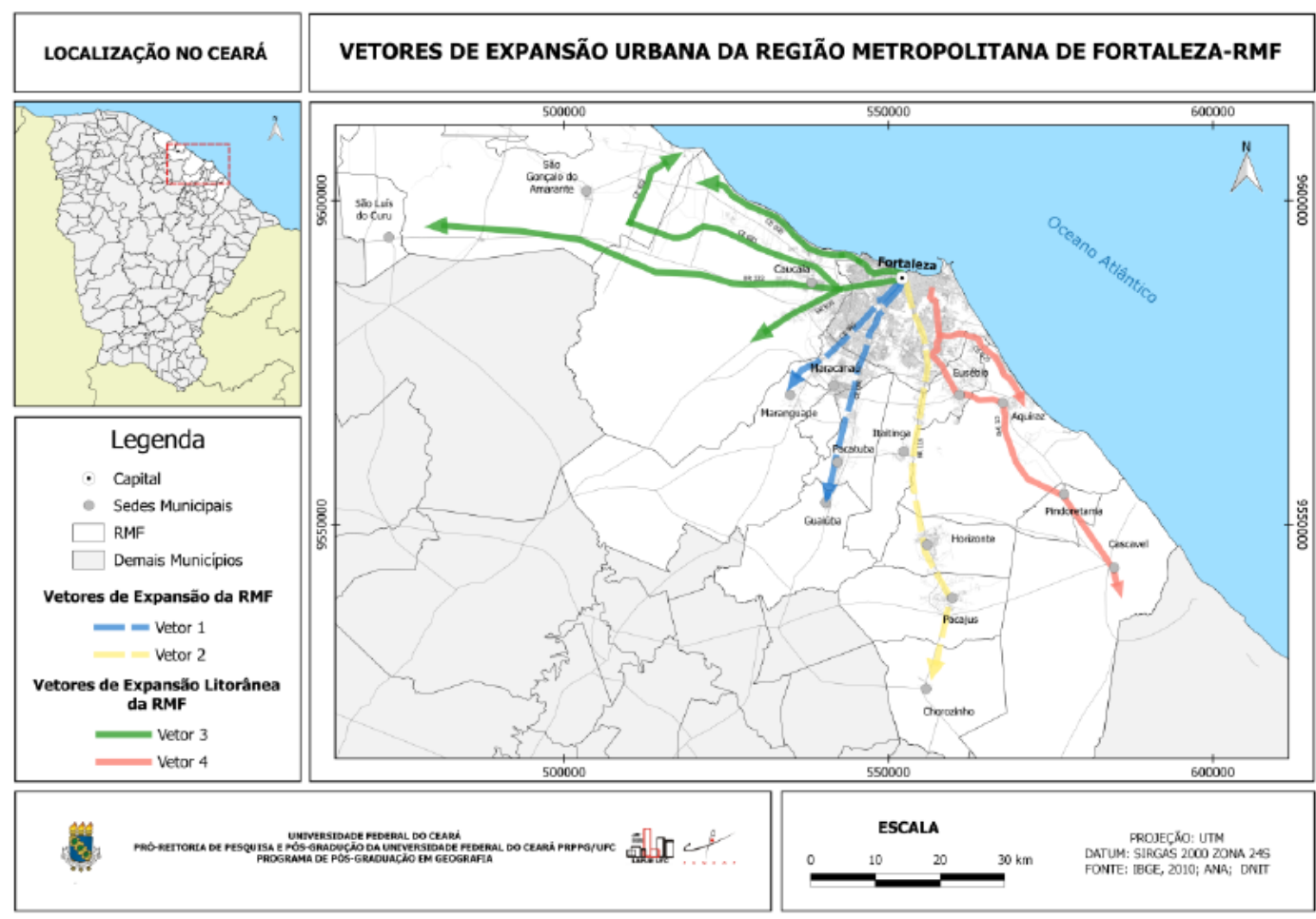

Fonte : CUNHA (2017)

Moura (2012) explica que no estágio contemporâneo da metropolização, emergem arranjos espaciais em contínua expansão e inúmeros conceitos são atribuídos aos que se consideram novas formas ou novos conteúdos da cidade e da aglomeração, nos processos de reconfiguração territorial.

Assim, os impactos dessas práticas (turismo e vilegiatura marítima) são refletidos no espaço em várias formas, sendo a mais representativa delas as novas formas imobiliárias e a morfologia urbana litorânea. O caso do litoral metropolitano de Fortaleza é analisado a seguir, ao compreender as duas principais espacialidades de lazer: a praia de Porto das Dunas, em Aquiraz, e a praia do Cumbuco, em Caucaia. Nesses subespaços, as funções e as formas urbanas alinham-se à faceta metropolizadora das atividades turísticas e de lazer. Assim, tratam-se de processos sociais que se desdobram em formas espaciais, formando centralidades do lazer. 


\section{Empreendimentos turístico-imobiliários e as formas urbanas litorâneas no Ceará}

As práticas associadas às dinâmicas de lazer são de suma importância no fenômeno da urbanização litorânea, na valoração das faixas de praia e na expansão do tecido urbano. A metropolização de Fortaleza se intensifica na Praia do Cumbuco, em Caucaia e no Porto das Dunas, em Aquiraz, sendo refletida nos complexos turísticos, condomínios, resorts, barracas de praia, parques aquáticos, práticas esportivas e banhos de sol e mar. As formas e os projetos transformam o intraurbano, na metrópole. As mudanças e os novos padrões apontam a inserção de outros espaços na reprodução do espaço urbano: os trechos à beira-mar de municípios continuamente integrados ao polo metropolitano.

A vilegiatura marítima e o turismo litorâneo, junto ao desejo do morar na praia, fomentam uma urbanização dispersa, fragmentada e expandida para os municípios do espaço metropolitano: Caucaia e Aquiraz. Simultaneamente, os empreendimentos e fluxos concentram-se e direcionam-se a recortes específicos do território, sobretudo, nas faixas à beira à mar.

Em Fortaleza, no final do século XIX e início do século XX, as práticas marítimas aqui desenvolvidas (pesca e atividades portuárias) ainda são consideradas tradicionais. Caminhadas à beira mar, tratamento terapêutico, serenatas (uma prática peculiar da cidade) e banhos de mar tornaram-se usos comuns desse espaço. É somente nas décadas de 1970 e 1980 que a urbanização da faixa de praia na zona leste de Fortaleza se intensifica: são construídos grandes edifícios para moradia de alto padrão, instalação de barracas de praia e a formação da rede hoteleira. Essa modificação de uso e valor desse espaço associa-se ao efeito de morar na praia - que ganha força com as elites - e com a criação de infraestrutura básica para criação do solo urbano e do preço da terra (DANTAS, 2010). Acrescenta-se a gestão desse período que visualizou a valorização da faixa litorânea, inseriu a atividade turística na cadeia econômica do estado e, dessa forma, investimentos foram pensados para essa integração.

A prática da vilegiatura marítima ocorre desde o século XX, podendo ser compreendida em dois grandes momentos: com a descoberta das zonas de praia para a moradia e o lazer a partir do século XX e com a incorporação dos municípios vizinhos. A consolidação dessa prática com sua expansão para todo o litoral do Ceará, sem planejamento institucional do Estado, ocorrem até a década de 1980, quando os planos de desenvolvimento para a zona costeira são pensados. Com o fenômeno da urbanização litorânea na década de 1970, a vilegiatura se expande para o espaço vizinho à cidade de Fortaleza, desenvolvendo-se nos 
municípios de Caucaia e Aquiraz. Fato esse comum e semelhante a outros casos no Nordeste brasileiro. As principais localidades procuradas nesse período eram as Praias de Iparana, Pacheco e Icaraí, em Caucaia e o Porto das Dunas, Iguape e Presídio no município de Aquiraz.

A aquisição de uma segunda residência (casa de praia/casa de veraneio) vinculada ao status de morar nas zonas de praia - mesmo que de formas diferenciadas (uso ocasional), fomenta transformações no espaço urbano da metrópole. As primeiras ocupações - anos 1960/70 - eram casas do tipo mansão e sítio (nas Praias de Iparana, Pacheco, Iguape e Prainha), Nos anos de 1980 - condomínios tradicionais a partir de loteamento (o caso da Praia do Icaraí) e em 1990/2000 - condomínios mais sofisticados, ainda não inclusos na tipologia de resort, na Praia do Porto das Dunas.

Os atrativos encontrados nessas localidades, além da praia, eram as áreas comuns dos condomínios (geralmente compostos por piscina e deck) e o entorno. Na Praia do Icaraí (Caucaia), dois equipamentos podem refletir essa prática: o clube aquático Icaraí Clube e a barraca de praia Kabana. O processo de urbanização da Praia do Icaraí, iniciado por uma demanda de lazer, propiciou uma rede de serviços diversificada, sendo uma das variáveis para a transformação das segundas residências em morar permanente (fenômeno dos anos 1990 e 2000). Já na Praia do Porto das Dunas, um dos grandes indutores foi o loteamento em quatro etapas de incorporação e a construção/ampliação do empreendimento parque aquático Beach Park.

Além das ações localizadas e dinâmicas impostas por consumidores e produtores locais do espaço litorâneo, entende-se que o planejamento urbano condicionou mudanças na gestão e no entendimento dos trechos à beira-mar. Se planejar remete ao futuro, a gestão está diretamente associada ao presente. Gerir significa administrar uma situação com os recursos presentemente disponíveis e tendo em vista as necessidades imediatas (SOUZA, 2006, p. 150). O planejamento nos espaços à beira mar tem sido encarado com protagonismo pelo Governo do Estado do Ceará, enquanto que a gestão é conduzida pelas municipalidades. Há também a ação contínua dos empresários do setor turístico e da construção civil/incorporação imobiliária.

As ferramentas de planejamento para gestão das zonas costeiras e para o turismo passam a ocorrer de forma mais ordenada e elaborada com o fim do governo militar, a crise do estado moderno e a reforma da Constituição de 1988. Aqui ocorre a descentralização do poder e a autonomia dos estados e municípios. É diante desse processo que a atividade turística cresce e ganha uma conotação econômica e rentável, principalmente, no Nordeste do Brasil. 
É necessário o diálogo sobre a política de turismo difundida pela região Nordeste e que gerou impactos tanto locais (e de ordem espacial, cultural e social) quanto nacional. Aqui, entra em cena a partir da década de 1990, o Programa de Desenvolvimento do Turismo no Nordeste - o PRODETUR - NE (que é analisado em três fases: I, II e Nacional) e o papel do Estado do Ceará como agente inovador para a diversificação da atividade turística na região. Atualmente, o Estado do Ceará desenvolve, com os mesmos objetivos e com recursos contratados em instituições financeiras internacionais, o Programa de Infraestrutura de Turismo (PROINFTUR).

O PRODETUR - NE foi um projeto de dimensão regional que alavancou políticas públicas de caráter local (estadual). A elaboração do PRODETUR tem uma relação com o processo de metropolização turística e de lazer. Citamos anteriormente que esse fenômeno vai além dos marcos institucional e ao abordar a sua relação com o desenvolvimento turístico é possível compreender isso. No caso cearense, as principais componentes de concentração dos investimentos do PRODETUR foram: rodovias e estradas de acesso às praias, saneamento básico e requalificação urbana das localidades e das zonas à beira-mar. Ao avaliar todas as etapas do programa, compreende-se que foram priorizadas localidades metropolitanas, com ênfase em Caucaia, o que reforça o papel da metrópole como indutora de processos. A criação de projetos pelos próprios estados e o fortalecimento do Banco do Nordeste aparece como fatores importantíssimos no reordenamento urbano e na criação de formas espaciais no litoral, sobretudo, metropolitano.

Quadro 1: Síntese dos principais investimentos do PRODETUR nas localidades em análise, valores em Reais

\begin{tabular}{|c|c|c|}
\hline Munícipio & Investimento & Valor (R\$) \\
\hline Fortaleza & $\begin{array}{c}\text { Reforma do Aeropor } \\
\text { to Internacional Pinto Martins }\end{array}$ & $73.187 .239,58$ \\
\hline Caucaia & Rodovia CE 085: Caucaia & $2.121 .706,11$ \\
\hline Caucaia & $\begin{array}{c}\text { Rodovia CE 085: Cumbuco a } \\
\text { Lagoa do Banana. }\end{array}$ & $516.174,20$ \\
\hline Caucaia & Rodovia CE 085: Entrada do \\
& Garrote Village. & $835.280,05$ \\
\hline São Gonçalo do Amarante & $\begin{array}{c}\text { Rodovia CE 085: Entre CE 421- } \\
\text { São Gonçalo do Amarante. }\end{array}$ & $2.064 .428,46$ \\
\hline São Gonçalo do Amarante & $\begin{array}{c}\text { Rodovia CE 085: São Gonçalo } \\
\text { do Amarante. }\end{array}$ & $1.055 .120,32$ \\
\hline
\end{tabular}


Empreendimentos turístico-imobiliários e a modernização dos litorais metropolizados - Fortaleza - Ceará

\begin{tabular}{|c|c|c|}
\hline São Gonçalo do Amarante & $\begin{array}{c}\text { Rodovia CE 085: Pecém } \\
\text { entroncamento Taíba. }\end{array}$ & $214.823,94$ \\
\hline São Gonçalo do Amarante & $\begin{array}{c}\text { Rodovia CE 085: Pecém } \\
\text { entroncamento Taíba/Siupé. }\end{array}$ & $427.322,57$ \\
\hline São Gonçalo do Amarante & $\begin{array}{c}\text { Rodovia CE 085: Pecém } \\
\text { entroncamento Taíba/Siupé }\end{array}$ & $263.747,36$ \\
\hline São Gonçalo do Amarante & $\begin{array}{c}\text { Saneamento Pecém: coleta de } \\
\text { água e esgoto. }\end{array}$ & $1.963 .124,24$ \\
\hline Caucaia & $\begin{array}{c}\text { Saneamento Icaraí, Iparana e } \\
\text { Pacheco: abastecimento de água. }\end{array}$ & $5.710 .960,17$ \\
\hline Caucaia & Saneamento Caucaia. & $4.738 .375,46$ \\
\hline São Gonçalo do Amarante & $\begin{array}{c}\text { Saneamento e abastecimento de } \\
\text { água em São Gonçalo. }\end{array}$ & $2.037 .929,32$ \\
\hline
\end{tabular}

Fonte: DANTAS (2010); CUNHA (2017).

Esse processo envolve diversos agentes e coloca a metrópole como espaço receptor de parcela significativa do fluxo turístico e, simultaneamente, gerador de demanda. Vacanciers, Estado, iniciativa privada e a sociedade são diretamente responsáveis pelo fenômeno da urbanização litorânea e a sua expansão no tecido metropolitano. $\mathrm{O}$ quadro 2 evidencia o crescente no quantitativo de domicílios de uso sazonal na região metropolitana de Fortaleza até o censo de 2010. Os de Aquiraz, Cascavel, Caucaia, Fortaleza são litorâneos e grandes concentradores deste tipo de imóvel.

\section{Quadro 2: Domicílios de uso ocasional na Região Metropolitana de Fortaleza}

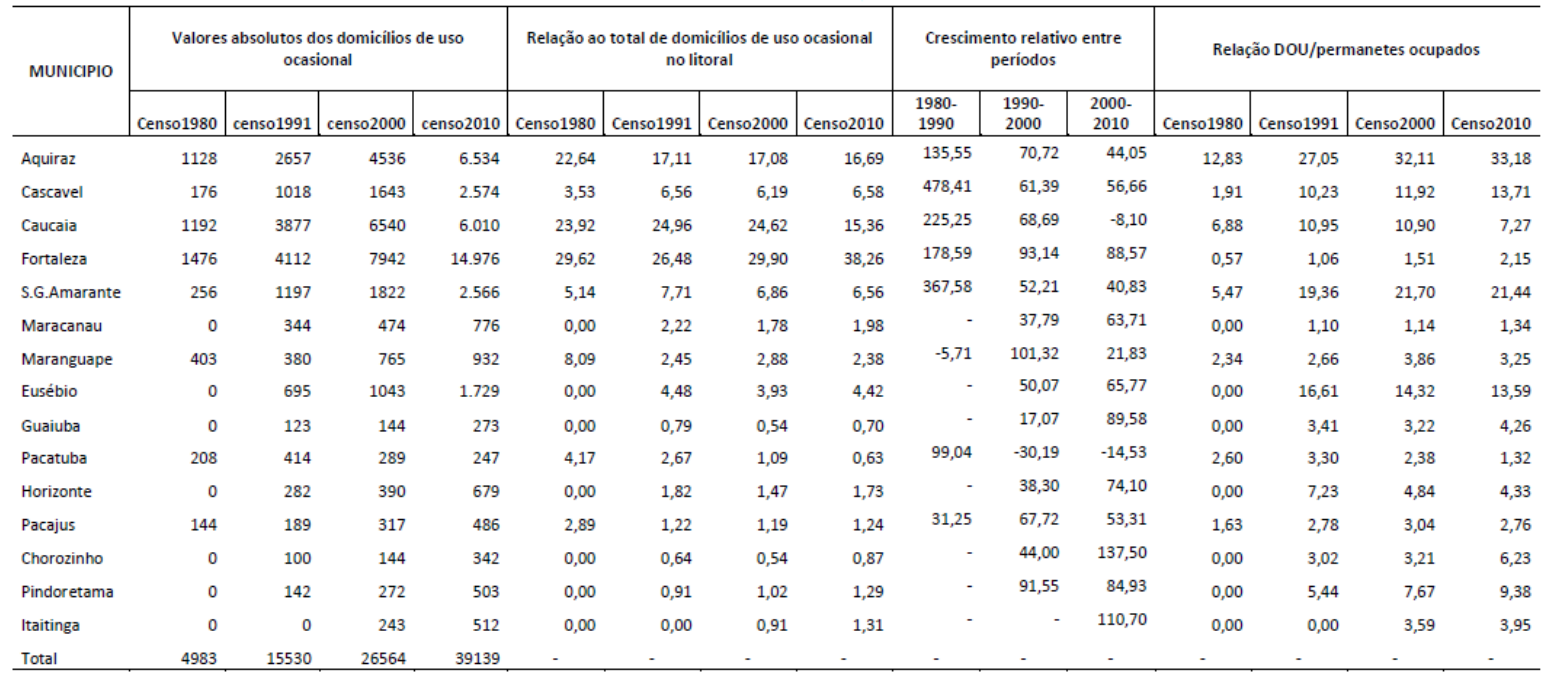

Fonte: IBGE, Sinopse do Censos de 1980, 1991, 2000 e 2010.

Fonte: IBGE (2010); PEREIRA (2012). 
A ocupação desses espaços, a demanda por lazer e o consumo fomentam a construção de equipamentos urbanos, de empreendimentos e atraem investimentos em infraestrutura. Nos trechos litorâneos dos municípios em análise foi possível visualizar a inserção empreendimentos turísticos-imobiliário e a transformação desses espaços em função do lazer. Aquiraz e Caucaia Ambos fazem parte do espaço metropolitano da metrópole, mas possuem certas particularidades relacionadas ao processo de urbanização litorânea. Concentram quase a totalidade dos empreendimentos imobiliários do estado, todavia apresentam vetores de expansão distintos. Enquanto na localidade do Cumbuco, em Caucaia, a expansão urbana associa-se a criação de equipamentos (restaurantes, barracas) e oferta de serviços na vila de pescadores, no Porto das Dunas, em Aquiraz, esse processo vincula-se a instalação do equipamento turístico Beach Park e de mais de uma dezena de resort/condomínios de médio e grande porte (Aquaville, GolfVille e Mandara).

Assim, a paisagem urbana litorânea desses municípios passou por transformações vinculadas ao contexto político e econômico. A análise da expansão urbana das localidades de Cumbuco (em Caucaia) e do Porto das Dunas (em Aquiraz) foi realizada em três períodos diferentes, a partir da década de 2000, quando os investimentos estrangeiros e nacionais no estado eram intensos e indicavam um padrão de consumo existente em outros países.

\section{Empreendimentos e formas urbanas em Porto das Dunas}

O município de Aquiraz recebeu o primeiro resort do Ceará em seu território em 1988. Depois de 20 anos continua atraindo cada vez mais investimentos tanto públicos como privados. A expansão da vilegiatura e do número de segundas residências propulsiona a expansão urbana e, também, o turismo. Essas duas atividades marítimas atraem recursos e investimentos do poder público e da iniciativa privada (incluindo, muitas vezes, capital estrangeiro) para a construção de novos empreendimentos e equipamentos turísticos. Como dito anteriormente, Porto das Dunas é a centralidade, principal área concentradora dos empreendimentos de turismo e lazer em Aquiraz.

O processo de expansão urbana da localidade do Porto das Dunas é pautado, principalmente, na construção de duas infraestruturas: a ponte sobre o rio Pacoti, ligando Fortaleza a localidade praiana e a inauguração do parque aquático Beach Park (hoje, o maior da América Latina). Na década de 1980 inicia-se um loteamento na localidade, sendo 
coordenado pelo interesse privado em transformar a área em espaço de lazer para os fortalezenses.

Porto das Dunas recebe investimentos voltados para o público de segundas residências e da atividade turística desde a década de 1980, principalmente, após a instalação do empreendimento Beach Park. Esse processo induziu a criação de infraestruturas hoteleiras para a localidade, criação de rodovia estadual de acesso (CE-025), fato intensificou o processo de metropolização. A CE-025, inserida na política de duplicação de estradas do Governo Estadual, liga Porto das Dunas a zona sudeste de Fortaleza, zona esta habitada por segmentos de média e alta renda.

Na década de 2000 fora inaugurado o primeiro condomínio da franquia Alphaville, denominado de Alphaville Fortaleza. Localizado em Eusébio, a menos de $2 \mathrm{~km}$ de Porto das Dunas, o condomínio atraiu a função do morar permanente de classe média alta. Diferentemente do que ocorreu na Praia do Icaraí (Caucaia), a instalação de grandes empreendimentos fomentou transformações em infraestrutura, mas não desenvolveu uma rede de serviços diversificada, tendo essa demanda concentrada em Fortaleza. Um desdobramento desse processo é a quantidade de domicílios de uso ocasional na localidade (mais de $50 \%)^{7}$ e, também, confirma a concentração de empreendimentos turísticos-imobiliário no município (dos oito grandes empreendimentos do estado, cinco localizam-se em Aquiraz). ${ }^{8}$ Rede de serviços e comércios pouco diversificados significa que os moradores e usuários desses trechos litorâneos buscam, nas centralidades urbanas constituídas em Fortaleza, o atendimento de suas necessidades no que tange a contratação de serviços e compra de mercadorias.

É válido ressaltar que ao longo do tempo as formas de uso e os usuários se modificam. Até a década de 1990, há uma predominância de usuários autóctones, ou seja, de público local (metropolitanos cearenses). A partir de 1990 crescem os fluxos turísticos de outros estados e em menor escala de outros países. Isso intensifica a prática da vilegiatura por alóctones e do turismo nacional-internacional.

\footnotetext{
${ }^{7}$ De acordo com dados do censo de 2010 do Instituto Brasileiro de Geografia e Estatística - IBGE, a média do número de domicílios de uso ocasional na localidade do Porto das Dunas é superior a 50\%.

${ }^{8}$ Outro exemplo é a instalação do empreendimento Aquiraz Riviera, na localidade da Tapera. Este complexo foi indutor de algumas transformações na localidade: como a criação de novas vias de acesso. O consumo desse espaço para morar permanente, já que o complexo possui um loteamento residencial, também corrobora para uma maior valoração das zonas de praias metropolitana.
} 
Compreende-se, hoje, que a vilegiatura não representa mais a fuga da cidade. É um dos vetores de expansão da metrópole e a reprodução do espaço urbano e metropolitano. Expansão esta materializada em empreendimentos para a moradia e para àquelas baseadas na sazonalidade das práticas de lazer. Para Dantas e Pereira (2013, p. 75) "a vilegiatura marítima difere de outras práticas de lazer porque não vivem como habitantes tradicionais; sua vida é regida pelo urbano. Embora de natureza "espontânea", sua permanência só se torna possível com a implantação de infraestrutura".

Se até os anos 1990, a ocupação da zona de praia era baseada na produção de segundas residências do tipo casa e sob a responsabilidade de cada proprietário, nos anos 2000 há mudança dos tipos. Nesse período (figura 2), é possível visualizar o crescimento urbano dessa localidade, que já nesse período, concentrava um grande número de empreendimentos de alto padrão, como o Aquaville Resort. É possível observar que os mega lotes a beira-mar passam a ser ocupados por empreendimentos multifamiliares com máximo de quatro pavimentos. Estes empreendimentos nascem com a ideia moderna de usos mistos: moradia, segunda residência, locações eventuais e realização de eventos do tipo shows e festivais.

Nesse mesmo período mudança de caráter normativo é efetivada. Trata-se da formulação do Plano Diretor de Desenvolvimento Urbano de Aquiraz. As leis de uso e ocupação do solo e de zoneamento ratificam o processo de expansão urbana das zonas de praia do município, com clara prioridade para usos e equipamentos de natureza turística.

Em 2011, observa-se um processo de expansão no sentido da conhecida Praia do Japão, contínua à praia do Beach Park. Insere-se na lógica a glebas destinadas a empreendimentos de padrão internacional. Também é possível visualizar construções em cima das dunas, o que é comum na localidade. No ano 2016, visualiza-se a consolidação dos empreendimentos a leste da localidade. São empreendimentos pautados no tipo condoresort, ocupando uma extensa área, cerca de $10 \mathrm{~km}$ (dos $36 \mathrm{~km}$ de faixa de praia de Aquiraz) e dotados de infraestrutura de lazer e serviços. Percebe-se que a expansão urbana da localidade ocorre no entorno do Beach Park. Esse espaço apresenta equipamentos turísticos de diversas categorias (entretenimento, comércio, serviços), sendo a maioria para a vilegiatura marítima de alto padrão. Encontram-se aqui empreendimentos imobiliários com integração direta ao Parque Beach Park e de investidores locais e internacionais (figura 3). Mesmo com a crise econômica de 2008 e anos seguintes, novos empreendimentos são construídos e suas unidades vendidas à clientela majoritariamente cearense. 
Os empreendimentos do balneário Porto das Dunas apresentam alto valor de mercado. Desde os primeiros equipamentos turístico-imobiliários, como o Aquaville Resort, até as instalações mais recentes - Mandara Kauai e Golf Ville -, percebe-se a valoração desses espaços em função do lazer, com imóveis de valor mínimo de quinhentos mil reais. Estes dois últimos empreendimentos são marco desta expansão, haja vista, sua construção ocupar terras distintas das loteadas dos anos 1980. Pode-se considerar que a partir de sua conclusão e comercialização, Porto das Dunas se estabelece como espacialidade do lazer marítimo na Região Metropolitana de Fortaleza. Observa-se processo de coesão espacial caracterizado pela aglomeração de empreendimentos e atração de fluxos de vacanciers.

Entende-se que as novas formas de uso ocasional buscam manter o visitante a maior parte do tempo dentro do empreendimento, para que usufrua de toda a infraestrutura de lazer e descanso oferecida. Essa característica é bem delimitada nos resorts, como explica Rosa e Tavares (2002, p. 87) "os resorts podem ser definidos como hotéis de lazer, situados fora dos centros urbanos, em locais que tenham alguma forma de atrativo natural e que sejam autocontidos". O termo autocontido reflete as novas opções de lazer oferecidas por esses equipamentos, englobando cada vez mais novos serviços (figura 4). Tais serviços associados à possibilidade de compra total do imóvel ou uso de sistemas de compartilhamento da propriedade com o timeshar ${ }^{9}$.

\footnotetext{
${ }^{9} \mathrm{O}$ sistema de timeshare permite a várias pessoas dividir o custo de um bem ou de um serviço. Nesse caso, seria a divisão do valor das diárias dos empreendimentos turístico-imobiliários ou sua manutenção.
} 
Figura 2: Expansão urbana da localidade do Porto das Dunas nos anos 2000, 2008 e 2016.

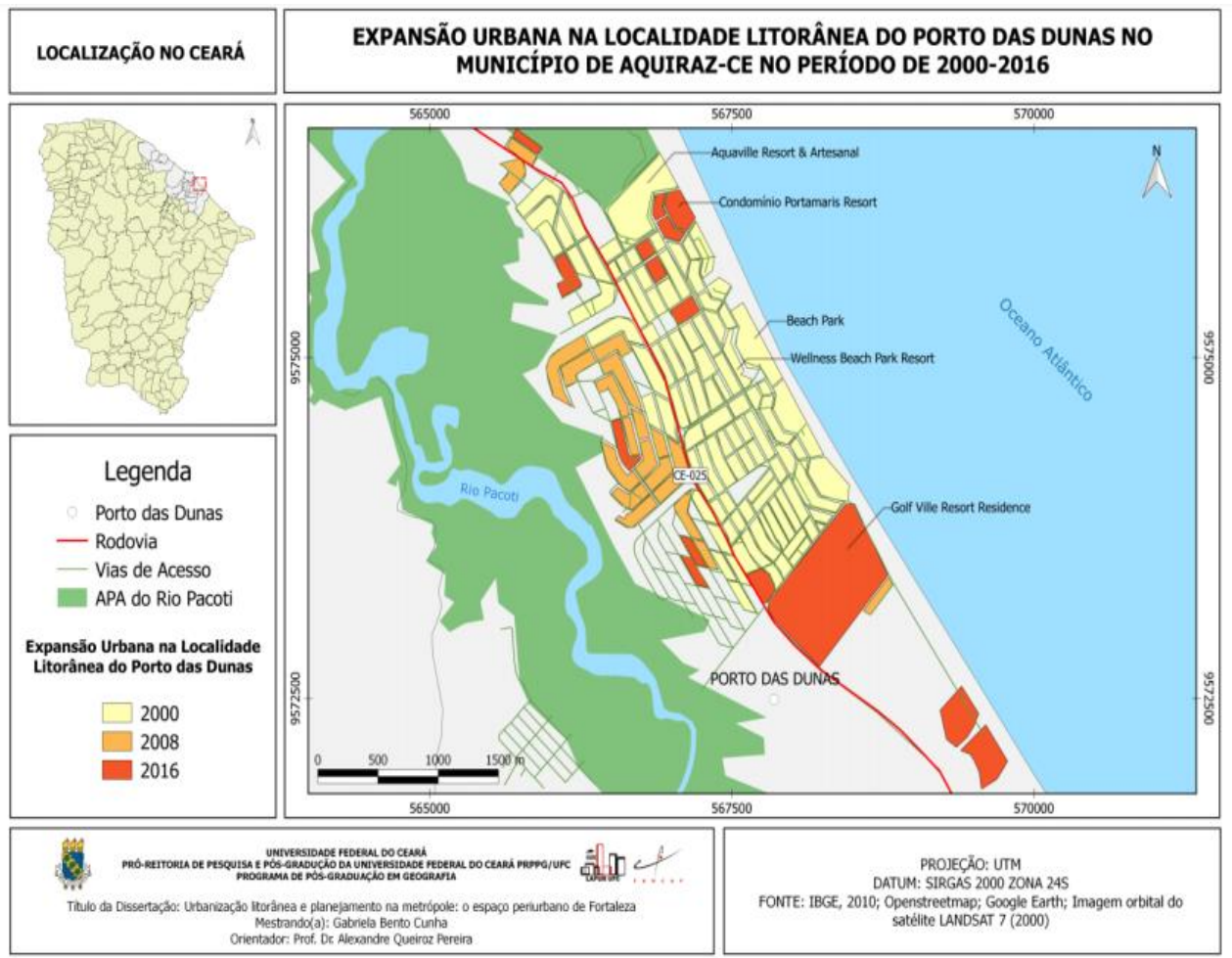

Fonte : CUNHA (2017)

Figura 3: Empreendimentos do tipo turísticos-imobiliário na Praia do Porto das Dunas, litoral leste.

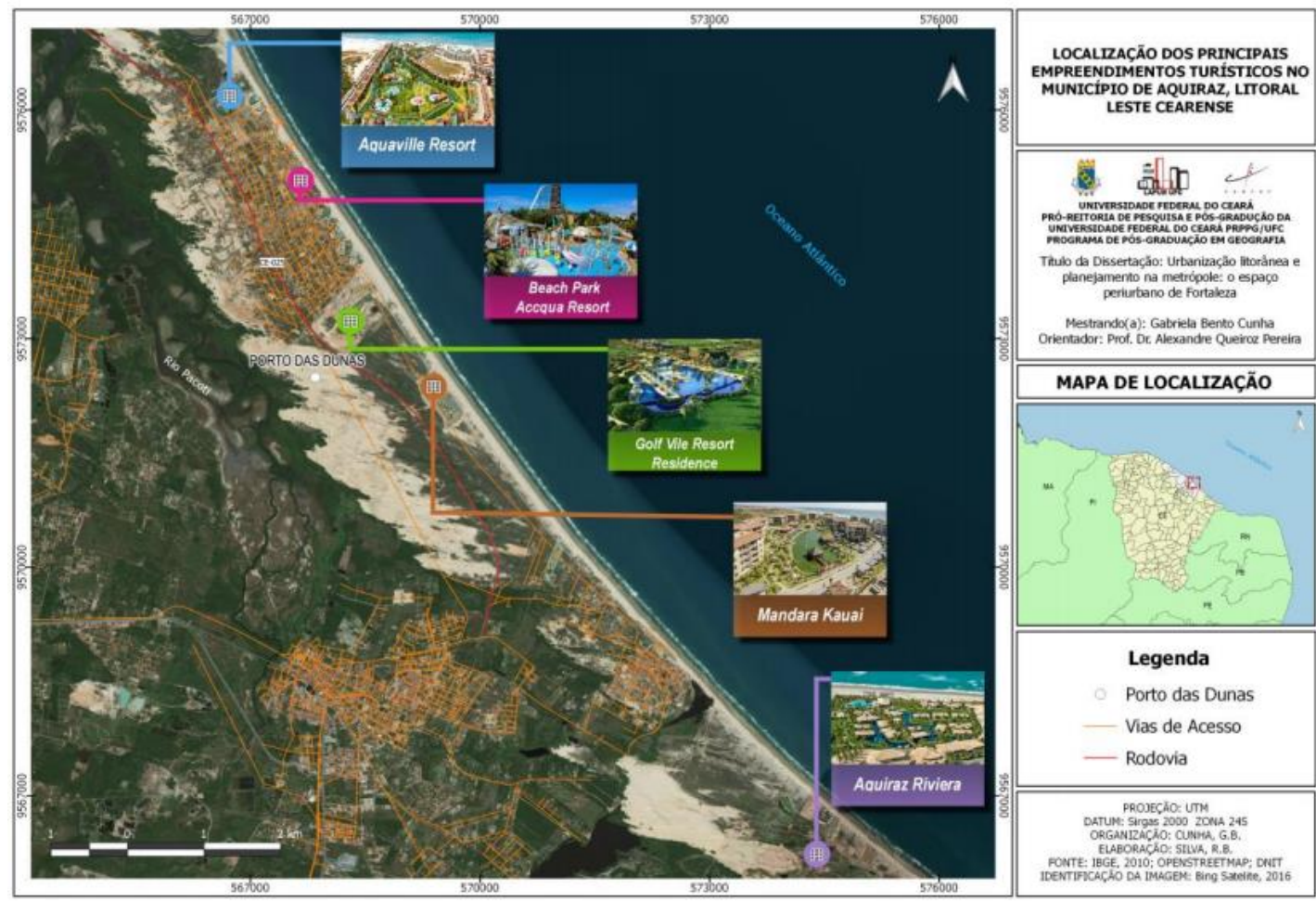

Fonte : CUNHA (2017) 
Figura 4: Detalhes sobre as áreas de lazer e espaços comuns de empreendimentos no Porto das Dunas.

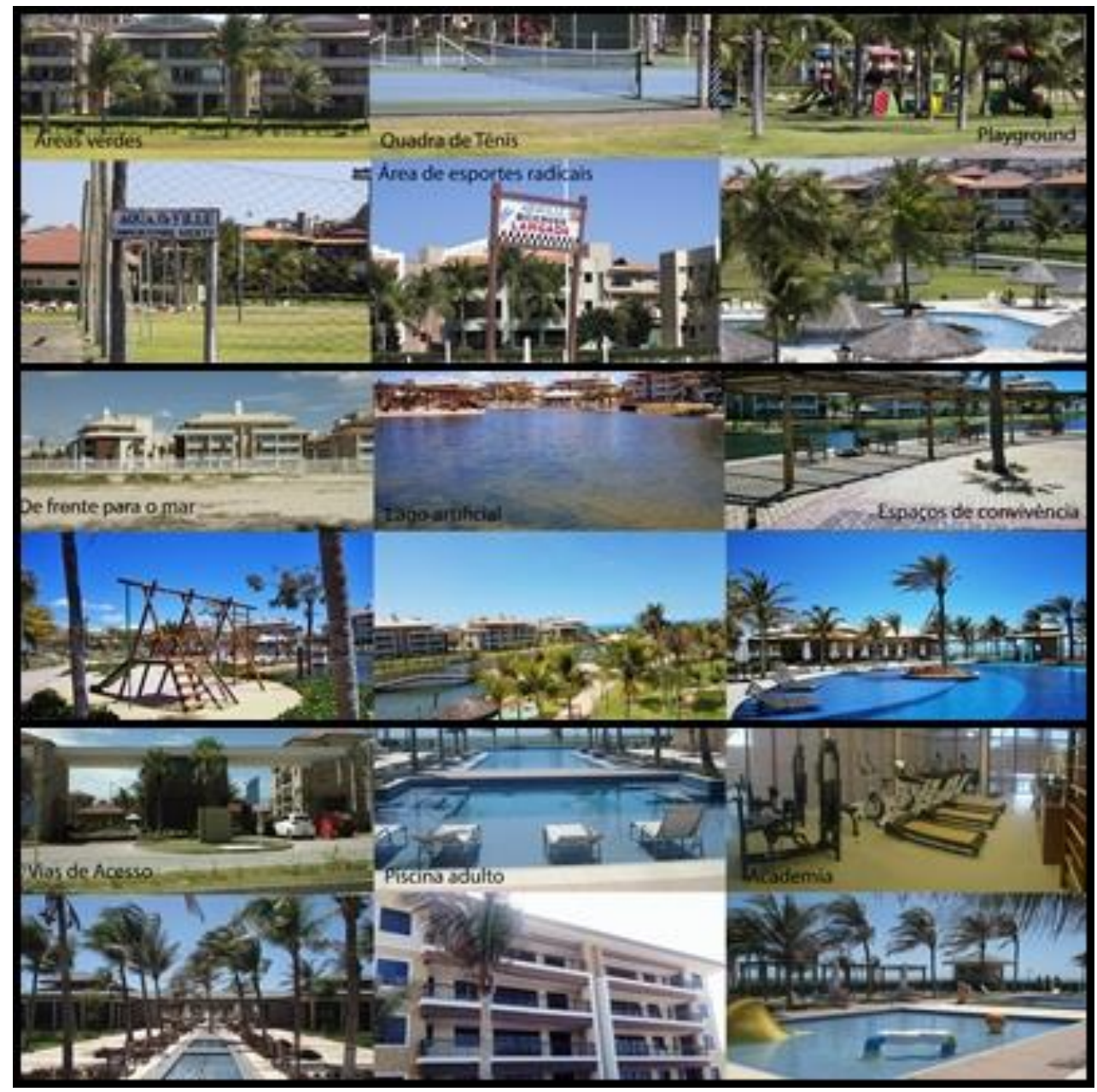

Fonte : CUNHA (2017)

Define-se que a praia do Porto das Dunas pode, também, ser considerada como um complexo turístico-imobiliário aberto, constituído de todas as modalidades do imobiliário e de serviços hoteleiros. Em Aquiraz é possível vislumbrar outro exemplo, só que fechado: o Aquiraz Riviera. Nele são oito grandes lotes divididos em resort, condoresort, condomínios horizontais e condomínio de bangalôs. No que concerne aos condoresort, entende-se esse tipo como um empreendimento que possui unidades para aquisição permanente, outras para aluguel e fornece a estrutura de um resort tradicional. A noção de complexo turístico-imobiliário aberto e fechado é desafio teórico, metodológico e conceitual a ser enfrentado em futuras pesquisas. 


\section{Empreendimentos e formas urbanas em Cumbuco}

O município de Caucaia é um dos mais importantes na metrópole cearense, sobremaneira, por sua integração à Fortaleza. Além do setor industrial, comércio e de serviços, o turismo apresenta-se como um vetor de expansão urbana e econômica para o município e o estado. Esse processo remonta a ocupação da Praia do Icaraí, nas décadas de 1980 e 1990, com a construção de condomínios tradicionais de veraneio e, hoje, reflete-se nas formas urbanas contemporâneas de lazer encontradas na Praia do Cumbuco.

O Cumbuco é continuidade espacial de faixa litorânea intensamente ocupada em Icaraí e agrega uma comunidade de pescadores de jangadas. É a partir dessa semente de ocupação que os espaços litorâneos foram loteados, sendo base para instalação dos futuros empreendimentos modernizadores da praia.

A paisagem urbana litorânea da localidade do Cumbuco associa-se inicialmente a casas de segundas residências de alto padrão. Até a década de 1980, Cumbuco não tinha nenhum empreendimento na tipologia de complexo turístico, apenas o projeto do hotel Saint-Tropez des Tropiques, de um grupo francês, pensado nos anos 1980, mas nunca efetivado. Tal projeto corresponde a primeira tentativa de atrair o público estrangeiro e apresentar uma praia pautada nos "moldes" das praias da América Central. A ausência de infraestrutura (apenas uma via de acesso), de sistema de telefonia e de serviços básicos impossibilitou a continuidade do projeto. O tipo imobiliário e de uso sazonal predominante na localidade até a década de 2000 foi o a segunda residência tipo mansão, produzida isoladamente.

Assim como em Porto das Dunas e Aquiraz, Cumbuco em Caucaia foi normatizado como área de expansão urbana no Plano Diretor de Desenvolvimento Urbano e suas leis associadas no início dos anos 2000. Ainda neste período, e não coincidentemente, as infraestruturas básicas foram instaladas com investimentos federais e estaduais das fases do PRODETUR/NE. Contudo, diferente de Porto das Dunas, apresenta heterogeneidade de conteúdo social e formas espaciais, principalmente, ao considerar as moradias de pescadores e outros moradores de baixa renda atraídos por oportunidades de empregos correlacionadas às atividades de lazer e turismo.

Os maiores e mais modernos empreendimentos foram construídos no final dos anos 2000. A instalação de empreendimentos do tipo turístico-imobiliários, notadamente o VG Sun (condomínio), Vila Galé (resort), Wai Wai Eco Residence (condomínio) e o Carmel Cumbuco (resort), transformam a mancha urbana do Cumbuco e apresentam-se como indutores de 
transformações no tecido urbano. Todavia, é importante destacar a relação os empreendimentos do mesmo grupo de origem portuguesa. Além da proximidade espacial, tem-se a complementariedade de funções, bem caracterizando a natureza do que se chama turismoimobiliário.

Os dois empreendimentos do grupo Vila Galé foram construídos em uma das áreas de expansão da ocupação da praia, com importante estoque de terras a beirar-mar disponíveis a incorporação de mesmo caráter: (VG Sun até a Barra do Cauípe). Nesse trecho há a instalação de duas estruturas: barraca de praia do grupo e uma casa de show - Café De La Musique -, presente em praias famosas do Brasil e do mundo e que recebe festas de diversos estilos, mas caracterizada por alto poder aquisitivo. Além, é possível perceber a criação de novas vias de acesso a esses equipamentos e a venda da imagem dessas localidades (figura 5), que altera o tecido urbano e a morfologia das cidades litorâneas (figuras 6 e 7). As estruturas viárias locais construídas com recursos dos públicos estaduais conferem as terras caráter de solo urbano.

É possível perceber esses formatos e sua distribuição a partir da representação cartográfica. Em 2004, já é perceptível uma ocupação paralela ao Atlântico e em lotes, que são representados por grandes mansões. Também é possível notar um grande espaço vazio no sentido oeste que, anos depois, será ocupado pelo maior empreendimento atual da localidade: o Hotel Vila Galé.

Figura 5: Estruturas construídas ao longo da extensão do Hotel Vila Galé.

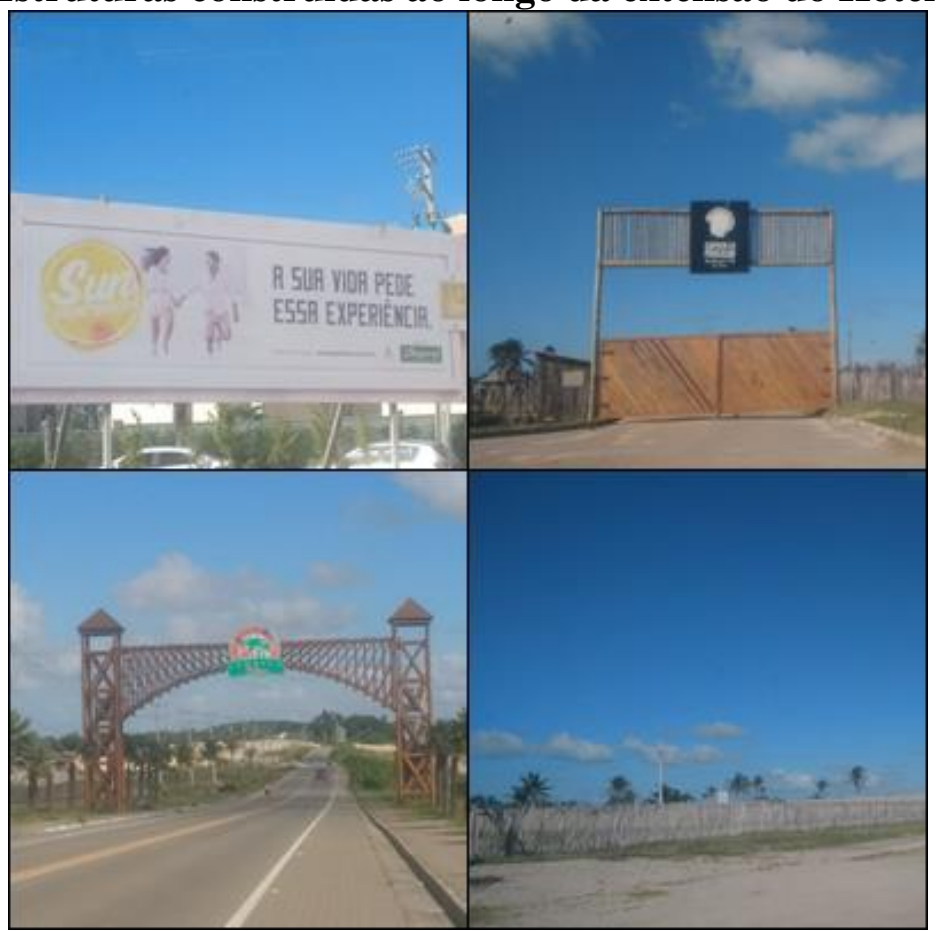

Fonte : CUNHA (2017) 
Na representação de 2010 percebe-se a construção do empreendimento Wai Wai Cumbuco Eco Residence Club. O empreendimento localiza-se na área destinada anteriormente ao hotel Saint-Tropez des Tropiques. São 260 apartamentos com três tipos de plantas e quatro tamanhos: 2, 3 e 5 quartos. O público alvo é o de primeira residência de alto padrão, com quase $80 \%$ das vendas direcionadas para cearenses, ocasionada principalmente pela degradação ambiental da Praia do Icaraí. O outro perfil de público encontrado é o de paulistas que buscam uma segunda residência. Os valores iniciais eram de quatrocentos mil reais para apartamentos de dois quartos, quinhentos mil reais para apartamentos de três quartos e de setecentos mil reais para apartamentos de cinco quartos. O empreendimento foi entregue em fevereiro de 2017, sendo completamente ecológico. Possui área de lazer completa com quadra de tênis, campo de futebol, quadra poliesportiva, game station, piscina, SPA, guarderia e sauna.

Na representação de 2016 já é possível visualizar uma construção intensa paralela à costa e próxima ocupação inicial da localidade. Também se percebe a construção do Hotel Vila Galé, na área de vazia a oeste da imagem e que aparece como um vetor de expansão urbana do Cumbuco. É válido ressaltar nessa imagem a ocupação das dunas, geralmente por antigos moradores da área central, também chamados de "nativos".

Figura 6: Expansão urbana da localidade do Cumbuco nos anos 2000, 2008 e 2016.

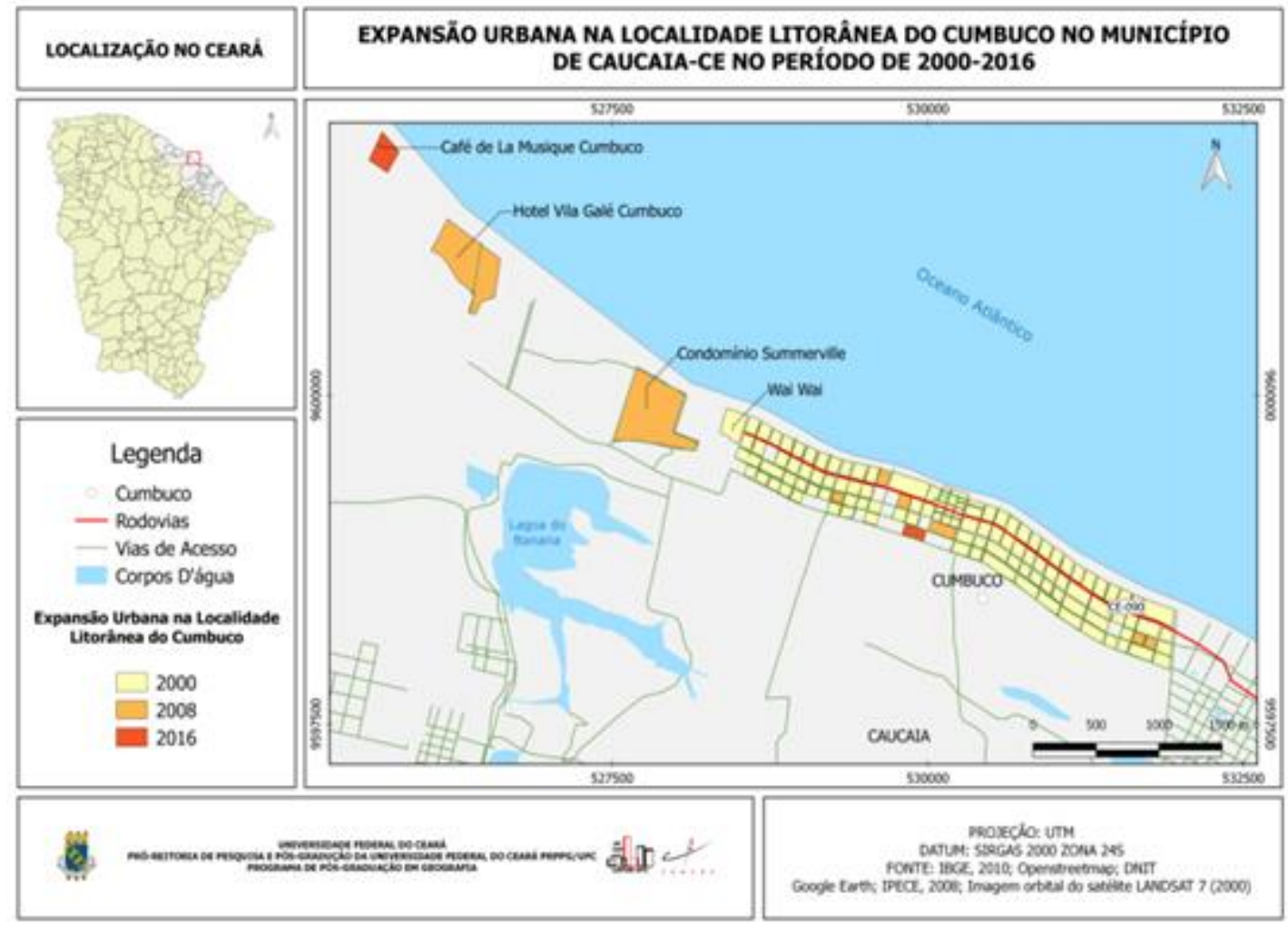

Fonte : CUNHA (2017) 
Na localidade do Cumbuco, a criação do Hotel Vila Galé induz a expansão urbana e a criação de novos equipamentos turísticos no sentido da localidade do Cauípe. Os empreendimentos inserem-se nos novos padrões de consumo e com tipos similares. A dinâmica do imobiliário turístico é de atração do público local, nacional e internacional, atendendo a vilegiatura marítima e ao turismo (RODRIGUES, 2015).

\section{Figura 7: Empreendimentos do tipo turísticos-imobiliário na Praia do Cumbuco, litoral} oeste.

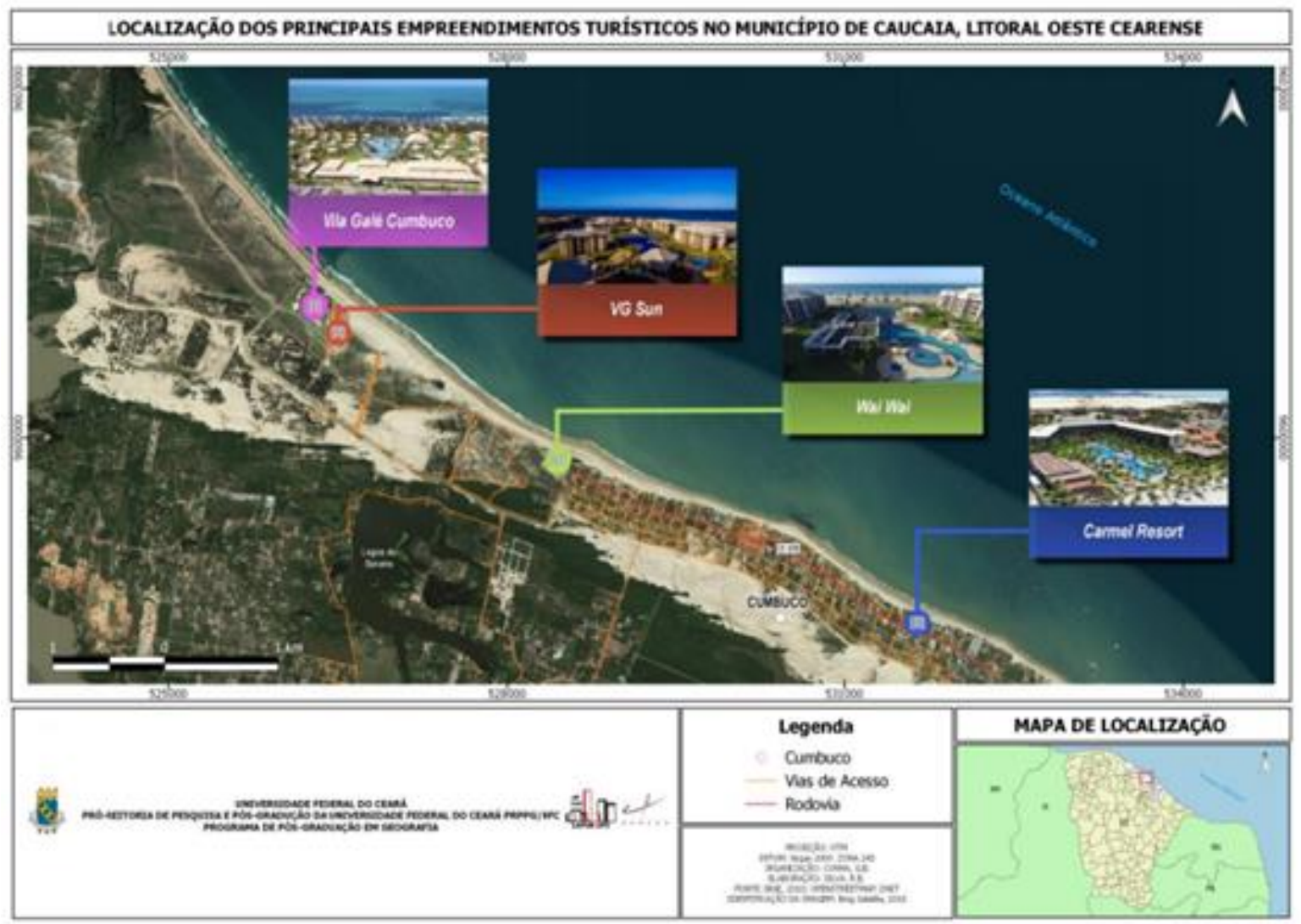

Fonte : CUNHA (2017)

O que se compreende hoje das tipologias imobiliárias e dos espaços de lazer dos empreendimentos é o novo padrão de consumo ofertado pelo mercado. Santos (1988, p. 32) explica que "as modernizações criam novas atividades ao responder a novas necessidades. As novas atividades beneficiam-se com as novas possibilidades, porém a modernização local pode representar simplesmente a adaptação de atividades já existentes a um novo grau de modernismo". A nova lógica do capital imobiliário incorpora hábitos e práticas que antes não eram associadas ao consumo local. 


\section{CONSIDERAÇÕES FINAIS}

Entende-se que as transformações culturais ocorridas no Brasil vinculam-se ao mundo contemporâneo e à troca de valores nos países ocidentais. Dessa forma, o papel da sociedade na transformação do espaço e da zona costeira ocorre também em virtude da necessidade de lazer, da incorporação econômica, da dinamização das zonas de praia e do discurso da reprodução do urbano.

A consequência dessa mudança cultural é refletida no padrão urbanístico das cidades, que ganham outra conotação: novos serviços são instalados, como a rede elétrica e o bonde e os padrões urbanos são incorporados gradativamente pela sociedade. Essas transformações tiveram início na região sul do país e depois se consolidam no Nordeste brasileiro.

Assim, a expansão do tecido urbano litorâneo nordestino tem início com as práticas tradicionais e a paisagem se modifica gradativamente, com os tratamentos terapêticos e as primeiras instalações de veraneio. $\mathrm{O}$ processo de valorização das zonas costeiras e a sua incorporação pelo lazer também se vincula a uma ação conjunta do planejamento público e da iniciativa privada, que desencadeiam novos processos e funções ao longo do tempo.

A metropolização reflete um espaço dinâmico, urbanizado, tecnificado, com relações socioespaciais diversificadas e inerentes ao processo de globalização e ao sistema capitalista. $\mathrm{O}$ processo de urbanização litorânea das cidades nordestinas engloba as transformações no modelo de sociedade: a valorização das zonas de praia como espaço de moradia (status para a elite) e de lazer (enquadram-se aqui tanto as práticas de turismo e vilegiatura e a praia como espaço de encontro e de relações sociais).

Constata-se que as políticas de planejamento geraram mudanças na infraestrutura da metrópole e, também, na vida das pessoas, mas é preciso ressaltar que o impacto desse planejamento não ocorre da forma que deveria. Enquanto as políticas públicas visam uma valorização dos espaços costeiros em sua totalidade, a influência da metrópole e seu papel como indutora de fluxos produz o desenvolvimento de alguns espaços em detrimento de outros. É dessa forma que se analisa como os impactos do planejamento não reproduzem o que foi proposto, pois acaba induzindo processos diferentes em localidades também diferentes.

As transformações socioespaciais, indicam uma articulação da metrópole Fortaleza com os demais municípios metropolitanos, mas é preciso indicar alguns apontamentos. A existência da metrópole e de sua supremacia política e econômica, mas como região, não há uma cultura metropolitana e nem um aparato legislativo para a gestão desses espaços de forma conjunta. A 
consequência disso é uma urbanização litorânea fragmentada e concentrada em áreas específicas à beira-mar. Para o litoral metropolitano de Fortaleza, Cumbuco e Porto das Dunas são os exemplos cabais. Nesses recortes territoriais foram-se complexos turísticos abertos e em processo de expansão. Situação esta representada pelo número de empreendimentos e a diversidade de funções que congregam.

Dessa forma, compreende-se que o fenômeno da urbanização litorânea não se restringe a um único fator. Ela não converge com as políticas públicas e nem se explica apenas pela demanda por lazer. $\mathrm{O}$ desejo pelo mar e pelo marítimo vincula-se a um processo de ordem cultural e social, que ocorreu em diversas cidades do mundo e que contribuíram para a construção da paisagem litorânea que conhecemos hoje. O planejamento público e privado se apresenta como dois vetores importantes na produção do espaço urbano e na valorização das zonas costeiras. Acrescenta-se a esse processo o papel da vilegiatura marítima e do turismo litorâneo, que junto ao desejo do morar na praia, fomentam uma urbanização dispersaconcentrada, fragmentada e expandida para os municípios do espaço metropolitano.

A análise da forma urbana - representada pela análise da expansão urbana - e das políticas públicas acaba por apontar os vetores de expansão da Metrópole e a relação direta com os municípios de Caucaia e Aquiraz. Consideração importante a ser feita é a relação entre o planejamento e a vilegiatura marítima, com foco na importância que essa prática adquire no processo de urbanização litorânea metropolitana. Nas localidades em análise, os investimentos diretos e indiretos decorrentes do poder público e da iniciativa privada induziram o crescimento da Vilegiatura Marítima (Cumbuco e Porto das Dunas) e fomentam o mercado de expansão urbana.

\section{REFERÊNCIAS}

ABREU, M. A. Evolução Urbana do Rio de Janeiro. Rio de Janeiro: IPLANRIO/ZAHAR, 2010

ALMEIDA, M. G. Turismo e os novos territórios no litoral cearense. In: Turismo e Geografia: reflexões teóricas e enfoques regionais. Editora HUCITEC, 1996.

ANDRADE, R. I.L. Dinâmicas e conflitos na zona costeira de Aquiraz: Porto das Dunas e Prainha em análise. Fortaleza, 2008. 150p. Dissertação (Mestrado Acadêmico em Geografia) Universidade Estadual do Ceará, Centro de Ciências e Tecnologia. 
ARAUJO, E. F. As políticas de turismo e os espaços litorâneos na região metropolitana de Fortaleza. Dissertação (Mestrado). Universidade Federal do Ceará, Fortaleza, 2012.

ARAUJO, E. F. As políticas públicas e os espaços turísticos no litoral da Região Metropolitana de Fortaleza. In: Maritimidade na Metrópole - Estudos sobre Fortaleza -CE. Porto Alegre: Liro, 2013.

BECKER, B. Políticas e planejamento do turismo no Brasil. In: TURISMO, ESPAÇO, PAISAGEM E CULTURA. Editora HUCITEC, São Paulo, 1995.

CARLOS, A. F. A. São Paulo: dinâmica urbana e metropolização. Revista Território - Rio de Janeiro - Ano VII -nº11, 12 e 13 - set./out., 2003. p.78.

DANTAS, E. W. C. Programa de Desenvolvimento do Turismo no Nordeste Brasileiro (1995 - 2005): PRODETUR-NE, o divisor de águas. In: TURISMO E IMOBILIÁRIO NAS METRÓPOLES. Rio de Janeiro: Letra Capital, 2010.

FERREIRA, A. L. A. SILVA, A. F. C. Dinâmica imobiliária e turismo: novas relações, novos riscos. In: Cadernos Metrópole: desigualdade e governança. Vol. 18, São Paulo: EDUC, 2007.

LENCIONI, S. Metropolização do espaço: processos e dinâmicas. In: Metropolização do espaço: gestão territorial e relações urbano-rural. Rio de Janeiro: Consequência, 2013.

LIMONAD, E. Urbanização dispersa: mais uma forma de expressão urbana?. Revista Formação, nº14 volume 1 - p. 31 - 45, 2006.

MOURA, R. A dimensão urbano-regional na metropolização contemporânea. Revista EURE, vol. 38, nº 115, pp. 5-31. Setembro, 2012.

PANIZZA, A. C.; PEREIRA, A.Q. Residências secundárias e estruturação socioespacial da zona costeira cearense, Brasil. Revista de Geografia (Londrina) v. 18, n. 2, 2009.

PEREIRA, A. Q. A urbanização vai à praia - Vilegiatura Marítima e Metrópole no Nordeste do Brasil. Fortaleza: Edições UFC, 2014.

PEREIRA, A. Q. A Vilegiatura Marítima na Metrópole: Morfologia e Tipologias espaciais. In: Maritimidade na Metrópole - Estudos sobre Fortaleza - CE. Porto Alegre: Liro, 2013.

PEREIRA, A. Q. A urbanização vai à praia: contribuições da Vilegiatura Marítima à metropolização do Nordeste do Brasil. Tese (doutorado). Universidade Federal do Ceará, Fortaleza, 2012.

RODRIGUES, A. A. B. Percalços do planejamento turístico: o PRODETUR-NE. In: Turismo e Geografia: reflexões teóricas e enfoques regionais. Editora HUCITEC, 1996.

RODRIGUES, L. C. Turismo em espaços urbanos: processos de turistificação no Nordeste brasileiro e no Caribe Mexicano. Revista Iberoamericana de Turismo - RITUR, Penedo, vol. 5, Número especial, p. 81-104, abril, 2015. 
Empreendimentos turístico-imobiliários e a modernização dos litorais metropolizados - Fortaleza - Ceará

Recebido em Junho de 2018

Aprovado em Dezembro de 2018

Publicado em Fevereiro de 2019 